\title{
Antibiotic Resistant Bacteria Found in Municipal Drinking Water
}

\author{
Sadia Khan $^{1,2^{*}}$, Charles W. Knapp ${ }^{1}$ and Tara K. Beattie ${ }^{1}$ \\ ${ }^{1 *}$ Department of Civil and Environmental Engineering, University of Strathclyde, \\ James Weir Building, Level 5, 75 Montrose Street, Glasgow, G1 1XJ, UK \\ Tel.: +44(0) 141548 320, Fax: +44 (0) 141 553-2066, \\ E-mail. sadia.khan@strath.ac.uk \\ ${ }^{2}$ Department of Environmental Engineering, NED University of Engineering and \\ Technology, University Road, Karachi-75270, Pakistan
}

\begin{abstract}
Multidrug resistant bacteria in water supply systems have been emerging as a growing public health concern. Many factors affect the source and fate of these bacteria. However, conditions in the plumbing systems may contribute in the dispersion of resistance genes among bacterial populations. Through the process of lateral gene transfer, resistance genetic material can be exchanged between species in the microbial population, intensifying the problem of resistance genes. The main aim of this study was to investigate the diversity of microorganisms in tap-water in Glasgow, Scotland, and the occurrence of certain antibiotic resistance genes and gene-transfer mechanisms. Results show that antibiotic resistant bacteria exist at the consumers' end of the distribution system, some of which also contain integrase genes, which can aid in the dispersion of resistance genes. Presence of such microorganisms indicates that further investigations should be taken to assess the risks to public health.
\end{abstract}


Key words: antimicrobial resistance, water distribution system, intI, qac, sul

\section{Highlights}

- $\quad$ Plumbing systems contain antibiotic resistance bacteria

- $\quad$ sul1 and sul2 genes are found in bacteria which show resistance against sulfonamides drugs

- The presence of integrons suggests that resistance traits can be transferred to other bacteria 


\section{Introduction}

Supply of safe drinking water to the population of the world remains one of the major concerns for public health. Many factors impact this provision, including increasing world population, limited freshwater resources, and pollution. Contemporary issues affecting supply include contamination with chemical compounds, e.g. pharmaceutical and personal care products, and biological agents, which can contribute to increase antimicrobial resistance in bacteria (Batt et al. 2006; Larsson et al. 2007; Fick et al. 2009; Pruden et al. 2013; Hartmann et al., 2014). The use of these chemicals has been increased to a point that propagation of antimicrobial resistance has become unavoidable, and it is now considered an emerging contaminant of concern in the environment (Pruden et al. 2006). In urban areas, water treatment plants utilise multiple technologies to remove many pollutants (Xu et al. 2007), while integrated constructed wetlands are used in rural areas for removal of pollutants and resistance genes (Chen et al. 2015a), however these systems are never entirely effective (Xu et al. 2007).

Various processes in the treatment plants (Armstrong et al. 1981), and the physical and chemical nature of the long distribution systems, facilitate the enrichment of bacteria and their genes. Attachment to particulates, capsule formation and increased tolerance of bacteria to chemical disinfectants help in the survival and spread of resistant organisms in water supply systems (Ridgway and Olson 1982; LeChevallier et al. 1984; LeChevallier et al. 1988; Bridier et al. 2011, Wingender and Flemming 2011).

The presence of antimicrobial resistant bacteria and their genes in water bodies is not limited to under-developed countries (Khan et al. 2013; Ahammad et al. 2014); they have been found in developed nations including Australia, Germany and the United Kingdom (Stoll et al. 2012). Many enteric bacteria with multiple drug resistance (MDR), e.g., Escherichia, Enterobacter, Klebsiella, Salmonella and Shigella species, have been found in drinking and recreational water resources (Kumar et al. 2013). Previously, both Gram-positive and Gram-negative bacteria, 
including Staphylococcus, Alcaligenes, and Acinetobacter species, have been reported in drinking-water distribution systems (Armstrong et al. 1981). Antibiotic resistant Pseudomonas species have also been isolated from drinking water (Vaz-Moreira et al. 2012; Ribeiro et al. 2014). The presence of MDR in the clinical environment makes the treatment of diseases difficult (Ashbolt et al. 2013); their presence in water bodies, and increased exposure risk, may necessitate enhanced water treatment and increase expense.

Bacteria isolated from drinking water may not only contain antibiotic resistance, they may also express resistance to commonly used disinfectants, including chlorine and monochloramine (Ridgway and Olson 1982; Chiao et al. 2014, Khan et al, 2016). These disinfectants are indispensable in water treatment plants to eradicate bacteria and minimise the growth of bacteria in the distribution system. Resistance develops upon exposure to subinhibitory concentrations over time, and a number of bacterial species with monochloramine resistance have been reported in drinking water, including: Coxiella, Desulfuromonas, Desulfomonile, Escherichia, Geobacter, Legionella, Mycobacterium, and Sphingomonas species (Chiao et al. 2014).

Besides physical and chemical processes, genetic factors contribute to the dispersion of resistance genes in drinking water distribution systems. Horizontal gene transfer (HGT) mechanisms move resistance genes from resistant to susceptible populations on mobile genetic elements like integrons (Mazel 2006; Gillings et al. 2008; Stalder et al. 2012; Jechalke et al. 2013). HGT spreads genetic elements and their genes among dissimilar groups of bacteria (Gaze et al. 2011), rapidly transferring antibiotic and disinfectant resistance genes (Boucher et al. 2007; Stokes and Gillings 2011; Mokracka et al. 2012). Integrons have a recombination system, which captures genes and serves as a reservoir of resistance genes (Stokes and Hall 1989; Demarre et al. 2007; Xu et al. 2011). The transfer of multiple genes on integrons via HGT intensifies the problem of resistance in bacterial communities, as it can link resistance 
traits between environmental bacteria and human pathogens in drinking water systems (Ribeiro et al. 2014).

Among multidrug resistance bacteria, class 1 integrons are most common (Shearer and Summers 2009), and they are related to the presence of resistance to quaternary ammonium compounds (QACs), qacE $\Delta 1$ genes and sulphonamide resistance sul1 determinants (Kucken et al. 2000). Almost half of the class 1 integrons contain a qac resistance genes cassette (Gillings et al. 2009), and the prevalence of class 1 integrons in bacteria having previous exposure to QACs is greater than those without previous exposure (Gaze et al. 2005). Moreover, bacteria that possess or acquired plasmids, transposons or integrons, have greater QACs resistance than those which do not have any of these genetic elements (Bjorland et al. 2003). Bacteria often show cross resistance for QACs and antibiotics (Morente et al. 2013), including the use of efflux-pump systems to generate resistance to unrelated broad-range antimicrobials (BuffetBataillon et al. 2012). Enzyme based mechanisms of antibiotic resistance is also found in bacteria. In the presence of antibiotics, bacteria may acquire genes encoding enzymes which can destroy the antibiotic before reaching the target, resulting in the development of resistant in bacteria (Tenover, 2006).

This study aimed to determine the prevalence of bacteria and resistance genes in drinking water. Assays included genes responsible for resistance to a wide variety of quaternary ammonium compounds (qac genes) and sulphonamide antibiotics (sul1 and sul2 genes), as these genes commonly co-occur. Mobile genetic integrons were detected via their integrase gene intI1 and intI2. The co-occurrence of sul and qac genes in bacteria from the water distribution system was also examined.

\section{Materials and Methods}

\subsection{Sampling and Processing}


Tap-water samples were collected from residences in Glasgow in sterile screw capped bottles, and were processed within 2-4 hours of collection. One hundred millilitres water samples were vacuum-filtered through $0.22 \mu \mathrm{m}$ pore size cellulose nitrate gridded membranes (Millipore, UK), which were then aseptically placed on Standard Plate Count Agar APHA (Oxoid, UK). The plates were incubated for 48 hours at $37 \pm 2{ }^{\circ} \mathrm{C}$. Selected bacterial isolates from the resultant growth were streaked on Nutrient Agar (Oxoid, UK) plates to isolate colonies; 4-5 colonies of each strain were preserved in glycerol using a Bacterial Beads Preservation Kit (Cryo vials TS/71-MX, Technical Service Consultants Ltd., UK) and stored at $-80{ }^{\circ} \mathrm{C}$.

\subsection{DNA Extraction and PCR Amplification}

DNA of the bacterial isolates were thermally extracted by mixing strains with $100 \mu \mathrm{L}$ of PBS ( $\mathrm{pH}$ 7.4) and undergoing a series of freeze thaw cycles at $-80{ }^{\circ} \mathrm{C}$ and $70{ }^{\circ} \mathrm{C}$ with continuous shaking between each cycle. The contents were centrifuged at 10,000 rpm for 5 minutes at the end of the fourth thermal cycle, and DNA from the supernatant was stored at $-80{ }^{\circ} \mathrm{C}$.

PCR reactions were performed with a Bio-Rad iQ5 Real-Time PCR Detection System for the presence of $16 \mathrm{~S}-\mathrm{rRNA}$, intI1, intI2, sul1, sul2 and qac genes using previously described primers (Table 1; Pei et al. 2006; Luo et al. 2010; Caporaso et al. 2011; Jechalke et al. 2013). Twenty microliter PCR reactions consisted of $10 \mu \mathrm{L}$ of MegaMix-Blue-PCR Mastermix with dye (Microzone Limited, UK), $1 \mu \mathrm{L}$ of each primer (500 $\eta \mathrm{M}$ final concentration; SigmaAldrich Life Science, UK), $6 \mu \mathrm{L}$ of nuclease-free water, and $3 \mu \mathrm{L}$ of DNA sample. Each PCR run consisted of initial denaturation at $95{ }^{\circ} \mathrm{C}$ for 3 minutes; this was followed by 40 cycles of denaturation at $95{ }^{\circ} \mathrm{C}$ for 30 seconds, annealing for 30 seconds at annealing temperature (Table 1), extension at $72{ }^{\circ} \mathrm{C}$ for 30 seconds, and then a final extension at $72{ }^{\circ} \mathrm{C}$ for 10 minutes. PCR products were further verified with $2 \%$ agarose gel in 1x Tris Acetate-EDTA buffer; the size of 
amplified products was determined against a 50-bp incrementing DNA ladder (Fisher BioReagent, UK).

\subsection{DNA Purification and Sequencing}

PCR products from 16S-rRNA gene amplification were purified using the QIAquick PCR Purification Kit (Qiagen, UK) according to the manufacturer's instructions. Purified and cleaned amplicon concentration was determined by the EPOCH ${ }^{\mathrm{TM}}$ Microplate spectrophotometer system (BioTek, UK). Amplicon was mixed with $5 \mu \mathrm{M}$ forward primer solution used in PCR in a 1:1 ratio in a total volume of $10 \mu \mathrm{L}$ and sent to LightRun Sequencing Service (GACT Biotech Ltd, London, UK) for sequencing. Bacteria were identified by comparing the sequences using the BLAST program through the National Centre for Biotechnology Information (NCBI).

\section{Results}

\subsection{Identification of Bacteria by16S-rRNA Sequencing: Bacterial Community Structure}

Bacteria were isolated from tap water by a membrane filtration method $(n=148)$ and 87 colonies were identified up to genus level by sequencing the V4 region of 16S-ribosomal RNA gene. The water distribution system harboured three phyla of bacteria: Proteobacteria, Actinobacteria and Firmicutes. Among them, $54(62.1 \%)$ belonged to the phylum Proteobacteria. Sub grouping of this phylum indicated the presence of 10 alpha-proteobacteria $(11.5 \%), 38$ beta-proteobacteria $(43.7 \%), 5$ gamma-proteobacteria $(5.7 \%)$ and 1 epsilonproteobacterium $(1.2 \%)$. Firmicutes were the second largest phyla found in drinking water and $18(20.7 \%)$ bacteria belonged to this group, while $15(17.2 \%)$ bacteria were from Actinobacteria. 
The presence of both Gram-negative and Gram-positive bacteria was confirmed in the tap water; among them some of the bacteria can be pathogenic. Species of Bacillus, Paenibacillus, Brevibacillus, Kocuria, Staphylococcus, Arthrobacter, Comamonas, Acidovorax, Blastomonas, Variovorax, Escherichia and pathogenic Burkholderia were found in the water distribution system.

\subsection{Presence of Antibiotic Resistance Genes}

Detection of the sul 1 and sul2 genes specific for sulfonamide resistance was performed on 148 isolates and these genes were detected in $12(8.1 \%)$ isolates, thus confirming the presence of antibiotic resistant bacteria in the water distribution system; none contained both genes. Sul1 genes were detected in $8(5.4 \%)$ bacteria, while sul2 genes were present in $4(2.7 \%)$ isolates (Table 2). In two (1.4\%) isolates, these genes were also positive for integrons, while in 10 $(6.8 \%)$ isolates they were found singly without integrase genes indicating that sul genes did not always correspond to intI genes as expected. This suggests that the sul genes in these bacteria might either be present on chromosome, or associated with other genetic elements (Gundogdu et al. 2011) other than intI genes. The distribution of bacteria containing antibiotic resistance genes (ARGs) was widespread among organisms including Bacillus, Cupriavidus, Variovorax, Kocuria, Ralstonia, Dermacoccus, Micrococcus and Staphylococcus species from the samples.

\subsection{Presence of Disinfectant Resistance Genes}

Disinfectant resistance genes qac were not found in any of the isolates. Qac genes associated with class 1 integrons have a high occurrence rate in the environment both in Gram-positive and Gram-negative bacteria (Jaglic and Cervinkova 2012); in this study, the presence of qac genes was not detected. 


\subsection{Presence of Transferable Markers}

PCR amplification analyses indicated that class-1 integrons existed in eight bacteria (9.2\%), while intI 2 genes were not detected in any isolate. In this study, Dermacoccus sp. had both sul1 and intI1 genes, while Micrococcus sp. had sul2 and intI1 genes simultaneously. Presence of intI1 genes confirms the presence of transferable genetic element integrons in the bacteria of the water supply system which could involve in the dispersion of antibiotic and disinfectant resistance genes in the environment.

\section{Discussion}

The presence of antibiotic resistant bacteria and their genes in water is a major public health concern and a global challenge (Pruden et al. 2012; Pruden et al. 2013). They are a major contributing factor in water pollution, found in natural water bodies (Ahammad et al. 2014), treated drinking water (Pruden et al. 2006), and drinking water distribution systems (Xi et al. 2009), can cause infectious diseases (Pruden et al. 2012), and are difficult to treat (Levy 2002). Currently, waterborne diseases are not only related to the presence of faecal bacteria, but also the occurrence of opportunistic pathogens in water systems (Wang et al. 2013). Around 30 different bacterial genera have been isolated from drinking water in different studies including genera of Pseudomonas, Klebsiella, Enterobacter, Escherichia and Proteus (Norton et al. 2000; Allen et al. 2004; Gallego et al. 2005, Chiao et al, 2014). In developed countries, outbreaks of waterborne infections due to the drinking water have been reported (Kilvington et al. 2004; Brunkard et al. 2011). Antibiotic resistant infections are also not uncommon in these countries. In the USA, two million people suffered from antibiotic resistant infections every year and among them 23,000 died (CDC 2013). Drinking water distribution systems host a variety of microorganisms (Simoes et al. 2010), and bacteria having antibiotic resistance can find their way into drinking water in these systems. From drinking water, they can colonize the 
gastrointestinal tract and serve as a potential health risk for the population, especially immunecompromise individuals (Lee et al. 2010).

Isolation of bacteria by membrane filtration demonstrates the presence of viable organisms, so it is a good indicator of the presence of living bacteria in the water environment, which can be actively involved in gene transfer among bacteria and spread of disease in humans. 16SrRNA gene information is generally used for the identification of bacteria from different environments (Chakravorty et al. 2007). While a useful housekeeping genetic marker to classify bacteria, 1-14 \% of organisms remain unidentified as it has low phylogenetic power at species level and cannot discriminate some genera properly (Drancourt et al. 2000; Woo et al. 2003; Mignard and Flandrois 2006; Janda and Abbott 2007). In this study, we identified $87 \%$ of bacteria from the tap water, while $13 \%$ of bacteria were not characterized as no significant similarity was found. These bacteria belong to 22 genera (Table 2), and also included Burkholderia, some species of which are waterborne pathogens and may cause melioidosis in humans (Howard and Inglis 2003). The isolation and identification of multiple types of bacteria at the point of use indicates that the distribution network or plumbing systems might be playing some role in the existence of these bacteria, and the ecology of the system could be a contributing factor in their incidence (Hong et al. 2010).

A well-recognized factor which could contribute to the existence of antibiotic resistance bacteria at the consumer end is the presence of biofilms in the distribution system or plumbing system of the buildings from where water samples have been taken. Prevalence of antibiotic resistant bacteria in a water supply system, even in the presence of disinfectant, could be exacerbated by aging infrastructure, in which biofilms have formed on surfaces (Abe et al. 2012). The multiple layers of microorganisms in these biofilms decrease the residual disinfectant levels to the inner layers; further, bacteria in these layers could develop and transfer resistance traits against antimicrobials to other susceptible populations present in these biofilms (Molin and Tolker-Nielsen 2003; Bridier et al. 2011). Water storage in tanks and 
cisterns also causes a decrease in the amount of residual disinfectant as water retention time increases, thus allowing bacteria to grow in water. Disinfection itself could concentrate the antibiotic resistant bacteria and their genes in drinking water, as was found in the work of Shi et al. (2013), where chlorination caused the enrichment of tet, amp and erm genes.

The emergence of antibiotic resistance in the environment is not only due to physiological factors, but also depends on genetic factors like horizontal gene transfer (HGT) rate (Andersson and Hughes 2010). Co-selection of two different antibiotic resistance genes occurs through HGT due to the genetic linkage of these genes. For example, sulfonamide resistance genes are plasmid borne and often linked with other antibiotic resistance genes. It has also been found that sul and intI genes co-exist in water, which might be due to the presence of sul1 genes on the class 1 integrons (Chen et al., 2015b). This contributes to the reason that sulphonamide resistance has not declined even when the use of the antibiotics has been reduced (Enne et al. 2004).

Quaternary ammonium compounds resistant genes are also present on mobile genetic elements, such as class 1 integrons (Chapman 2003). Bacterial strains, which acquire genetic units like plasmids, transposons or integrons, show a higher resistance to QACs (Bjorland et al. 2003). The selective pressure by quaternary ammonium compounds (Stalder et al. 2012) disperses qac genes and antibiotic resistance genes associated with the integrons (Paulsen et al. 1993; Paulsen et al. 1996; Jeong et al. 2009). This indicates that cross resistance for QACs and antibiotics is possible (Morente et al. 2013). Other mechanisms like a multidrug efflux pump and modification of the cell wall also induce resistance in bacteria (Jaglic et al. 2012), which allow them to survive in the presence of disinfectant. This could be a reason that in the current study, qac genes were not detected in any of the bacteria despite the fact that int $I 1$ genes were present with antibiotic resistance genes. This suggests that in the absence of disinfectant resistant genes, other mechanisms of resistance might help bacteria persist in the water distribution system. 


\section{Conclusions}

Isolation of antibiotic resistant bacteria from drinking water demonstrates a need for greater awareness of ecological interactions in drinking water and increased monitoring of distribution systems and plumbing. Presence of those genera, some species of which could cause human diseases, indicates that water quality could not be guaranteed at the consumer end, and future studies should focus on treatment considerations at point of use to guarantee safety.

\section{Acknowledgements}

$\mathrm{PhD}$ work of SK is supported by the "Faculty for the Future" grant scheme from Schlumberger Foundation.

An initial version of this paper has been presented at the 9th World Congress of the European Water Resources Association (EWRA) "Water Resources Management in a Changing World: Challenges and Opportunities", Istanbul, Turkey, June 10-13, 2015. 
Table 1. PCR Primers for targeting different genes

\begin{tabular}{|c|c|c|c|c|}
\hline Primer & Sequence $\left(5^{\prime}-3^{\prime}\right)$ & $\begin{array}{l}\text { PCR annealing } \\
\text { temperature }\left({ }^{\circ} \mathrm{C}\right)\end{array}$ & $\begin{array}{l}\text { Amplicon } \\
\text { size }\end{array}$ & Reference \\
\hline V4-16S-515F & TGTGCCAGCMGCCGCGGTAA & \multirow{2}{*}{50} & \multirow{2}{*}{312} & \multirow{2}{*}{ (Caporaso et al. 2011) } \\
\hline V4-16S-806R & GGCTACHVGGGTWTCTAAT & & & \\
\hline qacEaIIF & CGCATTTTATTTTCTTTCTCTGGTT & \multirow{2}{*}{60} & \multirow{2}{*}{ Not detected } & \multirow{2}{*}{ (Jechalke et al. 2013) } \\
\hline qacEaIIR & CCCGACCAGACTGCATAAGC & & & \\
\hline int1-F & GGCTTCGTGATGCCTGCTT & \multirow{2}{*}{57} & \multirow{2}{*}{148} & \multirow{2}{*}{ (Luo et al. 2010; Chen et al. 2015a) } \\
\hline int1-R & CATTCCTGGCCGTGGTTCT & & & \\
\hline int $2-\mathrm{F}$ & GTTATTTTATTGCTGGGATTAGGC & \multirow{2}{*}{56} & \multirow{2}{*}{166} & \multirow{2}{*}{ (Luo et al. 2010; Chen et al. 2015a) } \\
\hline int2-R & TTTTACGCTGCTGTATGGTGC & & & \\
\hline sul1-F & CGCACCGGAAACATCGCTGCAC & \multirow{2}{*}{56} & \multirow{2}{*}{163} & \multirow{2}{*}{ (Pei et al. 2006; Chen et al., 2015a) } \\
\hline sul1-R & TGAAGTTCCGCCGCAAGGCTCG & & & \\
\hline sul2-F & TCCGGTGGAGGCCGGTATCTGG & \multirow{2}{*}{60.8} & \multirow{2}{*}{191} & \multirow{2}{*}{ (Pei et al., 2006; Chen et al., 2015a) } \\
\hline sul2-R & CGGGAATGCCATCTGCCTTGAG & & & \\
\hline
\end{tabular}

F, forward; $R$, reverse 
Table 2. Detection of intI1, intI2, sul1, sul2 and qac genes in bacteria isolated from the drinking water distribution system.

\begin{tabular}{|c|c|c|c|c|c|c|c|c|}
\hline \multirow[t]{2}{*}{$\mathbf{N \#}$} & \multirow[t]{2}{*}{ Phylum } & \multirow[t]{2}{*}{ Genus } & \multicolumn{5}{|c|}{ Genes } & \multirow[t]{2}{*}{ Isolate identification } \\
\hline & & & intI1 & intI2 & sul1 & sul2 & $q a c$ & \\
\hline 1 & Actinobacteria & Arthrobacter & - & - & - & - & - & $\mathrm{DW}(518)$ \\
\hline 1 & Actinobacteria & Arthrobacter & + & - & - & - & - & DW(509) \\
\hline 2 & Actinobacteria & Dermacoccus & - & - & - & - & - & $\mathrm{DW}(597,603)$ \\
\hline 1 & Actinobacteria & Dermacoccus & - & - & + & - & - & DW(608) \\
\hline 1 & Actinobacteria & Dermacoccus & + & - & + & - & - & DW(607) \\
\hline 1 & Actinobacteria & Dietzia & - & - & - & - & - & DW(625) \\
\hline 1 & Actinobacteria & Janibacter & - & - & - & - & - & DW(644) \\
\hline 1 & Actinobacteria & Kocuria & - & - & - & - & - & $\mathrm{DW}(565)$ \\
\hline 1 & Actinobacteria & Kocuria & - & - & + & - & - & DW(620) \\
\hline 1 & Actinobacteria & Kocuria & + & - & - & - & - & DW(513) \\
\hline 2 & Actinobacteria & Micrococcus & - & - & - & - & - & $\operatorname{DW}(505,637)$ \\
\hline 1 & Actinobacteria & Micrococcus & + & - & - & - & - & DW(638) \\
\hline 1 & Actinobacteria & Micrococcus & + & - & - & + & - & $\mathrm{DW}(512)$ \\
\hline 9 & Alphaproteobacteria & Blastomonas & - & - & - & - & - & $\begin{array}{l}\mathrm{DW}(525,526,547,551,553,554,556,559 \text {, } \\
599)\end{array}$ \\
\hline 1 & Alphaproteobacteria & Sphingomonas & - & - & - & - & - & $\mathrm{DW}(576)$ \\
\hline 8 & Betaproteobacteria & Acidovorax & - & - & - & - & - & $\mathrm{DW}(516,521,537,539,540,541,544,569)$ \\
\hline 5 & Betaproteobacteria & Burkholderia & - & - & - & - & - & $\operatorname{DW}(530,615,617,626,643)$ \\
\hline 1 & Betaproteobacteria & Comamonas & - & - & - & - & - & $\mathrm{DW}(503)$ \\
\hline 10 & Betaproteobacteria & Cupriavidus & - & - & - & - & - & $\begin{array}{l}\mathrm{DW}(501,502,504,511,522,570,578,580 \text {, } \\
587,591)\end{array}$ \\
\hline 1 & Betaproteobacteria & Cupriavidus & - & - & - & + & - & $\mathrm{DW}(515)$ \\
\hline 2 & Betaproteobacteria & Cupriavidus & - & - & + & - & - & $\mathrm{DW}(610,622)$ \\
\hline 1 & Betaproteobacteria & Cupriavidus & + & - & - & - & - & $\mathrm{DW}(604)$ \\
\hline 5 & Betaproteobacteria & Ralstonia & - & - & - & - & - & $\operatorname{DW}(609,613,616,618,619)$ \\
\hline 1 & Betaproteobacteria & Ralstonia & - & - & - & + & - & DW(614) \\
\hline 2 & Betaproteobacteria & Variovorax & - & - & - & - & - & $\mathrm{DW}(546,549)$ \\
\hline 2 & Betaproteobacteria & Variovorax & + & - & - & - & - & $\mathrm{DW}(557,600)$ \\
\hline 1 & Epsilonproteobacteria & Not identified & & & & & & DW(533) \\
\hline 5 & Firmicutes & Bacillus & - & - & - & - & - & $\mathrm{DW}(514,527,529,531,640)$ \\
\hline 1 & Firmicutes & Bacillus & - & - & - & + & - & $\mathrm{DW}(507)$ \\
\hline 1 & Firmicutes & Bacillus & - & - & + & - & - & $\mathrm{DW}(532)$ \\
\hline 1 & Firmicutes & Brevibacillus & - & - & - & - & - & $\operatorname{DW}(535)$ \\
\hline 5 & Firmicutes & Paenibacillus & - & - & - & - & - & $\operatorname{DW}(552,623,634,635,641)$ \\
\hline 1 & Firmicutes & Paenibacillus & - & - & + & - & - & $\mathrm{DW}(536)$ \\
\hline 3 & Firmicutes & Staphylococcus & - & - & - & - & - & $\operatorname{DW}(538,542,632)$ \\
\hline 1 & Firmicutes & Staphylococcus & - & - & + & - & - & DW(631) \\
\hline 2 & Gammaproteobacteria & Enhydrobacter & - & - & - & - & - & $\mathrm{DW}(506,508)$ \\
\hline 2 & Gammaproteobacteria & Escherichia & - & - & - & - & - & $\mathrm{DW}(560,611)$ \\
\hline 1 & Gammaproteobacteria & Pantoea & - & - & - & - & - & DW(595) \\
\hline
\end{tabular}




\section{Conflict of Interest}

No conflict of interest is found. 


\section{References}

Abe Y, Skali-Lami S, Block J-C, Francius G (2012) Cohesiveness and hydrodynamic properties of young drinking water biofilms. Water Res 46(4):1155-1166. doi: doi:10.1016/j.watres.2011.12.013.

Ahammad ZS, Sreekrishnan T R, Hands CL, Knapp CW, Graham DW (2014) Increased waterborne blaNDM-1 resistance gene abundances associated with seasonal human pilgrimages to the upper ganges river. Environ Sci Technol 48(5):3014-3020. doi: 10.1021/es405348h.

Allen MJ, Edberg SC, Reasoner DJ (2004) Heterotrophic plate count bacteria: what is their significance in drinking water? Int $\mathbf{J}$ Food Microbiol 92(3):265-274. doi: 10.1016/j.ijfoodmicro.2003.08.017.

Andersson DI, Hughes D (2010) Antibiotic resistance and its cost: is it possible to reverse resistance? Nature Rev Microbiol 8(4):260-271. doi: 10.1038/nrmicro2319.

Armstrong JL, Shigeno DS, Calomiris JJ, Seidler RJ (1981) Antibiotic-resistant bacteria in drinking water. Appl Environ Microb 42(2):277-283.

Ashbolt NJ, Amezquita A, Backhaus T, Borriello P, Brandt KK, Collignon P, Anja C, Finley R, Gaze WH, Heberer T, Lawrence JR, Larsson DGJ, McEwen SA, Ryan JJ, Schonfeld J, Silley P, Snape RJ, Eede CV, Topp E (2013) Human health risk assessment (HHRA) for environmental development and transfer of antibiotic resistance. Environ Health Perspect 121(9):993-1001. doi: 10.1289/ehp.1206316.

Batt AL, Snow DD, Aga DS (2006) Occurrence of sulfonamide antimicrobials in private water wells in Washington County, Idaho, USA. Chemosphere 64(11):1963-1971. doi: 10.1016/j.chemosphere.2006.01.029.

Bjorland J, Steinum T, Sunde M, Waage S, Heir E (2003) Novel plasmid-borne gene qacJ mediates resistance to quaternary ammonium compounds in equine Staphylococcus aureus, Staphylococcus simulans, and Staphylococcus intermedius. Antimicrob Agents Chemother 47(10):3046-3052. doi: 10.1128/AAC.47.10.3046-3052.2003. 
Boucher Y, Labbate M, Koenig JE, Stokes HW (2007) Integrons: mobilizable platforms that promote genetic diversity in bacteria. Trends Microbiol 15(7):301-309. doi: 10.1016/j.tim.2007.05.004.

Bridier A, Briandet R, Thoma V, Dubios-Brissonnet F (2011) Resistance of bacterial biofilms to $\begin{array}{llll}\text { disinfectants: } & \text { a } & \text { review. } & \text { Biofouling }\end{array}$ doi:10.1080/08927014.2011.626899.

Brunkard JM, Ailes E, Roberts VA, Hill V, Hilborn ED, Craun GF, Rajasingham A, Kahler A, Garrison L, Hicks L, Carpenter J, Wade TJ, Beach MJ, Yoder JS (2011) Surveillance for waterborne disease outbreaks associated with drinking water. United States, 2007-2008. Morbity Mortal. Weekly Rep 60 (ss12), 38-68.

Buffet-Bataillon S, Tattevin P, Bonnaure-Mallet M, Jolivet-Gougeon A (2012) Emergence of resistance to antibacterial agents: the role of quaternary ammonium compounds-a critical review. Int J Antimicrob Agents 39(5):381-389. doi: 10.1016/j.ijantimicag.2012.01.011.

Caporaso JG, Lauber CL, Walters WA, Berg-Lyons D, Lozupone CA, Turnbaugh PJ, Fierer N, Knight R (2011) Global patterns of 16S-rRNA diversity at a depth of millions of sequences per sample. Proc Natl Acad Sci USA 108 Suppl 1:4516-4522. doi: 10.1073/pnas.1000080107. CDC (2013) Antibiotic resistance threats in the United States, 2013. Center for Disease Control and Prevention, U. S. Department of Health and Human Servises, USA p. 1-114.

Chakravorty S, Helb D, Burday M, Connell N, Alland D (2007) A detailed analysis of 16S ribosomal RNA gene segments for the diagnosis of pathogenic bacteria. J Microbiol Methods 69(2):330-339. doi: 10.1016/j.mimet.2007.02.005.

Chapman JS (2003) Disinfectant resistance mechanisms, cross-resistance, and co-resistance. Int Biodeter Biodegr 51(4):271-276. doi: 10.1016/s0964-8305(03)00044-1.

Chen J, Liu YS, Su HC, Ying GG, Liu F, Liu SS, He LY, Chen ZF, Yang YQ, Chen FR (2015a) Removal of antibiotics and antibiotic resistance genes in rural wastewater by an integrated 
constructed wetland. Environ Sci Pollut Res Int 22:1794-1803. doi: 10.1007/s11356-0142800-4.

Chen B, Liang X, Nie X, Huang X, Zou S, Li X (2015b). The role of class I integrons in the dissemination of sulfonamide resistance genes in the Pearl River and Pearl River Estuary, South China. J Hazard Mater 282: 61-67. doi: 10.1016/j.jhazmat.2014.06.010.

Chiao T-H, Clancy TM, Pinto A, Xi C, Raskin L (2014) Differential resistance of drinking water bacteial populations to monochloriamine disinfection. Environ Sci Technol 48:4038-4047. doi: dx.doi.org/10.1021/es4055725.

Demarre G, Frumerie C, Gopaul DN, Mazel D (2007) Identification of key structural determinants of the IntI1 integron integrase that influence attC $\mathrm{x}$ attI1 recombination efficiency. Nucleic Acids Res 35(19):6475-6489. doi: 10.1093/nar/gkm709.

Drancourt M, Bollet C, Carlioz A, Martelin R, Gayral J-P, Raoult D (2000) 16S ribosomal DNA sequence analysis of a large collection of environmental and clinical unidentifiable bacterial isolates. J Clin Microbiol 38(10):3623-3630.

Enne VI, Bennett PM, Livermore DM, Hall LM (2004) Enhancement of host fitness by the sul2coding plasmid p9123 in the absence of selective pressure. J Antimicrob Chemoth 53(6):958963. doi: 10.1093/jac/dkh217.

Fick J, Soderstrom H, Lindberg RH, Phan C, Tysklind M, Larsson DGJ (2009) Contamination of surface, ground and drinking water from pharmateutical production. Environ Toxicol Chem 28(12): 2522-2527. doi:10.1897/09-073.S1.

Gallego V, Garcia MT, Ventosa A (2005) Methylobacterium hispanicum sp. nov. and Methylobacterium aquaticum sp. nov., isolated from drinking water. Int J Syst Evol Microbiol 55(Pt 1):281-287. doi: 10.1099/ijs.0.63319-0.

Gaze WH, Abdouslam N, Hawkey PM, Wellington EM (2005) Incidence of class 1 integrons in a quaternary ammonium compound-polluted environment. Antimicrob Agents Chemother 49(5):1802-1807. doi: 10.1128/AAC.49.5.1802-1807.2005. 
Gaze WH, Zhang L, Abdouslam NA, Hawkey PM, Calvo-Bado L, Royle J, Brown H, Davis S, Kay P, Boxall AB, Wellington EM (2011) Impacts of anthropogenic activity on the ecology of class 1 integrons and integron-associated genes in the environment. ISME J 5(8):1253-1261. doi: 10.1038/ismej.2011.15.

Gillings M, Boucher Y, Labbate M, Holmes, A, Krishnan S, Holley M, Stokes HW (2008) The evolution of class 1 integrons and the rise of antibiotic resistance. J Bacteriol 190(14):50955100. doi: 10.1128/JB.00152-08.

Gillings MR, Xuejun D, Hardwick SA, Holley MP, Stokes H W (2009) Gene cassettes encoding resistance to quaternary ammonium compounds: a role in the origin of clinical class 1 integrons? ISME J 3(2):209-215. doi: 10.1038/ismej.2008.98.

Gundogdu A, Long YB, Vollmerhausen TL, Katouli M (2011) Antimicrobial resistance and distribution of sul genes and integron-associated intI genes among uropathogenic Escherichia coli in Queensland, Australia. J Med Microbiol 60(Pt 11):1633-1642. doi: 10.1099/jmm.0.034140-0.

Hartmann J, Beyer R, Harm S (2014) Effective removal of estrogens from drinking water and wastewater by adsorption technology. Environ Process, 1, 87-94. doi: 10.1007/s40710-0140005-y

Hong PY, Hwang C, Ling F, Andersen GL, LeChevallier MW, Liu W T (2010) Pyrosequencing analysis of bacterial biofilm communities in water meters of a drinking water distribution system. Appl Environ Microb 76(16):5631-5635. doi: 10.1128/AEM.00281-10.

Howard K, Inglis TJJ (2003) The effect of free chlorine on Burkholderia pseudomallei in potable water. Water Res 37:4425-4432. doi: 10.1016/S0043-1354(03)00440-8

Jaglic Z, Cervinkova D (2012) Genetic basis of resistance to quaternary ammonium compounds the qac genes and their role: a review. Vet Med 57(6):275-281. 
Janda JM, Abbott SL (2007) 16S-rRNA gene sequencing for bacterial identification in the diagnostic laboratory: pluses, perils, and pitfalls. J Clin Microbiol 45(9):2761-2764. doi: 10.1128/JCM.01228-07.

Jechalke S, Schreiter S, Wolters B, Dealtry S, Heuer H, Smalla K (2013) Widespread dissemination of class 1 integron components in soils and related ecosystems as revealed by cultivationindependent analysis. Front Microbiol 4:420-427. doi: 10.3389/fmicb.2013.00420.

Jeong JH, Shin KS, Lee JW, Park EJ, Son SY (2009) Analysis of a novel class 1 integron containing metallo-beta-lactamase gene VIM-2 in Pseudomonas aeruginosa. J Microbiol 47(6):753-759. doi: 10.1007/s12275-008-0272-2.

Khan GA, Berglund B, Khan KM, Lindgren PE, Fick J (2013) Occurrence and abundance of antibiotics and resistance genes in rivers, canal and near drug formulation facilities-a study in Pakistan. PLoS One 8(6):e62712. doi: 10.1371/journal.pone.0062712.

Khan S, Beattie TK, Knapp CW (2016) Relationship between antibiotic- and disinfectant-resistant profiles in bacteria harvested from tap water. Chemosphere (In Press). doi:org/10.1016/j.chemosphere.2016.02.086.

Kilvington S, Gray T, Dart J, Morlet N, Beeching JR, Frazer DG, Matheson M (2004) Acanthamoeba Keratitis: The role of domestic tap water contamination in the United Kingdom. Invest Ophthal Vis Sci 45(1):165-169. doi: 10.1167/iovs.03-0559.

Kucken D, Feucht H-H, Kaulfers P-M (2000) Association of qacE and qacE1 with muptiple resistance to antibiotics and antiseptics in clinical isolates of Gram-negative bacteria. FEMS Microbiol Lett 183:95-98. doi: org/10.1111/j.1574-6968.2000.tb08939.x

Kumar S, Tripathi VR, Garg SK (2013) Antibiotic resistance and genetic diversity in water-borne Enterobacteriaceae isolates from recreational and drinking water sources. Int J Environ Sci Technol 10:789-798. doi: doi: 10.1007/s13762-012-0126-7. 
Larsson DGJ, Pedro CD, Paxeus N (2007) Effluent from drug manufacturers contains extremely high levels of pharmaceuticals. J Hazard Mater 148:751-755. doi: doi:10.1016/j.jhazmat.2007.07.008.

LeChevallier MW, Hassenauer TS, Camper AK, McFeters GA (1984) Disinfection of bacteria attached to granular activated carbon. Appl Environ Microbiol 48(5):918-923.

LeChevallier MW, Cawthon CD, Lee RG (1988) Factors promoting survival of bacteria in chlorinated water supplies. Appl Environ Microbiol 53(4):649-654.

Lee J, Lee CS, Hugunin KM, Maute CJ, Dysko RC (2010) Bacteria from drinking water supply and their fate in gastrointestinal tracts of germ-free mice: a phylogenetic comparison study. Water Res 44(17):5050-5058. doi: 10.1016/j.watres.2010.07.027.

Levy SB (2002) Factors impacting on the problem of antibiotic resistance. J Antimicrob Chemother 49:25-30.

Luo Y, Mao D, Rysz M, Zhou Q, Zhang H, Xu L, Alvarez PJJ (2010) Trends in antibiotic resistance genes occurrence in the Haihe River, China. Environ Sci Technol 44(19):72207225. doi: 10.1021/es100233w.

Mazel D (2006) Integrons: agents of bacterial evolution. Nature Rev Microb 4(8):608-620. doi: 10.1038/nrmicro1462. doi: 10.1038/nrmicro1462.

Mignard S, Flandrois JP (2006) 16S-rRNA sequencing in routine bacterial identification: a 30month experiment. J Microbiol Methods 67(3):574-581. doi: 10.1016/j.mimet.2006.05.009.

Mokracka J, Koczura R, Kaznowski A (2012) Multiresistant Enterobacteriaceae with class 1 and class 2 integrons in a municipal wastewater treatment plant. Water Res 46(10):3353-3363. doi: 10.1016/j.watres.2012.03.037.

Molin S, Tolker-Nielsen T (2003) Gene transfer occurs with enhanced efficiency in biofilms and induces enhanced stabilisation of the biofilm structure. Curr Opin Biotechnol 14(3):255-261. doi: 10.1016/s0958-1669(03)00036-3. 
Morente OE, Fernandez-Fuentes MA, Grande Burgos MJ, Abriouel H, Perez Pulido R, Galvez A (2013) Biocide tolerance in bacteria. Int J Food Microbiol 162(1):13-25. doi: 10.1016/j.ijfoodmicro.2012.12.028.

Norton CD, LeChevallier MW (2000) A pilot study of bacteriological population changes through potable water treatment and distribution. Appl Environ Microbiol 66(1):268-276.

Paulsen IT, Littlejohn TG, Rådström P, Sundström L, Sköld O, Swedberg G, Skurray RA (1993) The 3' conserved segment of integrons contains a gene associated with multidrug resistance to antiseptics and disinfectants. Antimicrob Agents Chemother 37(4):761-768. doi: 10.1128/AAC.37.4.761.

Paulsen IT, Brown MH, Littlejohn TG, Michell BA, Skurry RA (1996) Multidrug resistance proteins QacA and QacB from Staphylococcus aureus: Membrane topology and identification of residues involved in substrate specificity. Proc Natl Acad Sci USA 93:3630-3635.

Pei R, Kim S-C, Carlson KH, Pruden A (2006) Effect of river landscape on the sediment concentrations of antibiotics and corresponding antibiotic resistance genes (ARG). Water Res 40(12):2427-2435. doi: 10.1016/j.watres.2006.04.017.

Pruden A, Pei R, Storteboom H, Carlson KH (2006) Antibiotic resistance genes as emerging contaminants: Studies in Northern Colorado. Environ SciTechnol 40(23):7445-7450. doi: 10.102/es0604131.

Pruden A, Arabi M, Storteboom HN (2012) Correlation between upstream human activities and riverine antibiotic resistance genes. Environ Sci Technol 46(21):11541-11549. doi: dx.doi.org/10.1021/es302657r.

Pruden A, Larsson DGJ, Amezquita A, Collignon P, Brandt KK, Graham DW, Lazorchak JM, Suzuki S, Silley P, Snape JR, Topp E, Zhang T, Zhu Y-G (2013) Management options for reducing the release of antibiotics and antibiotic resistance genes to the environment. Environ Health Perspect 121(8):878-886. doi: http:/dx.doi.org/10.1289/ehp.1206446. 
Ribeiro AF, Bodilis J, Alonso L, Buquet S, Feuilloley M, Dupont J-P, Pawlak B (2014) Occurrence of multi-antibiotic resistant Pseudomonas spp. in drinking water produced from karstic hydrosystems. Sci Total Environ 490:370-378. doi: 10.1016/j.scitotenv.2014.05.012.

Ridgway HF, Olson BH (1982) Chlorine resistance patterns of bacteria from two drinking water distribution systems. Appl Environ Microbiol 44(4):972-987.

Shearer JE, Summers AO (2009) Intracellular steady-state concentration of integron recombination products varies with integrase level and growth phase. J Mol Biol 386(2):316-331. doi: 10.1016/j.jmb.2008.12.041.

Shi P, Jia S, Zhang XX, Zhang T, Cheng S, Li A (2013) Metagenomic insights into chlorination effects on microbial antibiotic resistance in drinking water. Water Res 47(1):111-120. doi: 10.1016/j.watres.2012.09.046.

Simoes LC, Simoes M, Vieira MJ (2010) Influence of the diversity of bacterial isolates from drinking water on resistance of biofilms to disinfection. Appl Environ Microbiol 78(19):66736679. doi: 10.1128/AEM.00872-10.

Stalder T, Barraud O, Casellas M, Dagot C, Ploy MC (2012) Integron involvement in environmental spread of antibiotic resistance. Front Microbiol 3:119-132. doi: 10.3389/fmicb.2012.00119.

Stokes HW, Hall RM (1989) A novel family of potentially mobile DNA elements encoding sitespecific gene-integration functions: integrons. Mol Microbiol 3(12):1669-1683.

Stokes HW, Gillings MR (2011) Gene flow, mobile genetic elements and the recruitment of antibiotic resistance genes into Gram-negative pathogens. FEMS Microbiol Rev 35(5):790819. doi: 10.1111/j.1574-6976.2011.00273.x.

Stoll C, Sidhu JP, Tiehm A, Toze S (2012) Prevalence of clinically relevant antibiotic resistance genes in surface water samples collected from Germany and Australia. Environ Sci Technol 46(17):9716-9726. doi: 10.1021/es302020s. 
Tenover FC (2006) Mechanisms of antimicrobial resistance in bacteria. Am J Med, 119 (6A): S310. doi. 10.1016/j.amjmed.2006.03.011.

Vaz-Moreira I, Nunes OC, Manaia CM (2012) Diversity and antibiotic resistance in Pseudomonas spp. from drinking water. SciTotal Environ 426:366-374. doi: doi:10.1016/j.scitotenv.2012.03.046.

Wang H, Edwards MA, 111 JOF, Pruden A (2013) Probiotic approach to pathogen control in premise plumbing systems? A Review. Environ Sci Technol 47:10117-10128. doi: dx.doi.org/10.1021/es402455r.

Wingender J, Flemming HC (2011) Biofilms in drinking water and their role as reservoir for pathogens. Int J Hyg Envir Heal 214(6):417-423. doi: 10.1016/j.ijheh.2011.05.009.

Woo PCY, Ng KHL, Lau SKP, Yip Kt, Fung AMY, Leung Kw, et al (2003) Usefulness of the MicroSeq 500 16S Ribosomal DNA-Based bacterial identification system for identification of clinically significant bacterial isolates with ambiguous biochemical profiles. J Clin Microbiol 41(5):1996-2001. doi: 10.1128/jcm.41.5.1996-2001.2003.

Xi C, Zhang Y, Marrs CF, Ye W, Simon C, Foxman B, Nriagu J (2009) Prevalence of antibiotic resistance in drinking water treatment and distribution systems. Appl Environ Microbiol 75(17):5714-5718. doi: 10.1128/AEM.00382-09.

Xu W, Zhang G, Li X, Zou S, Li P, Hu Z, Li J (2007) Occurrence and elimination of antibiotics at four sewage treatment plants in the Pearl River Delta (PRD), South China. Water Res 41(19):4526-4534. doi: 10.1016/j.watres.2007.06.023.

Xu Z, Li L, Shirtliff ME, Peters BM, Li B, Peng Y, Alam MJ, Yamasaki S, Shi L (2011) Resistance class 1 integron in clinical methicillin-resistant Staphylococcus aureus strains in southern China, 2001-2006. Clin Microbiol Infec 17(5):714-718. doi: 10.1111/j.14690691.2010.03379.x. 